
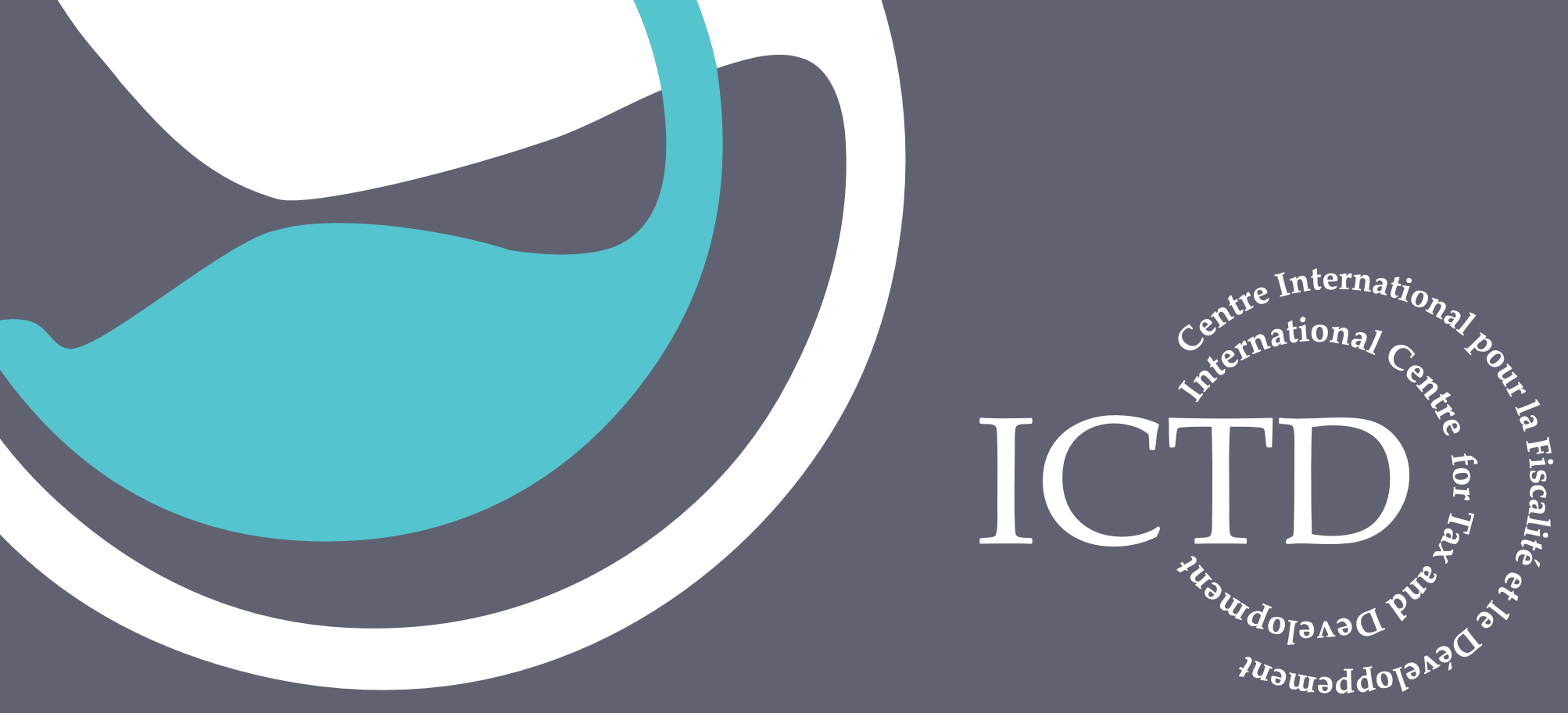

Working Paper 39

\title{
What Do We Know about Mineral Resource Rent Sharing in Affrica?
}

Bertrand Laporte and Céline de Quatrebarbes August 2015 
ICTD Working Paper 39

What Do We Know about Mineral Resource
Rent Sharing in Africa?

Bertrand Laporte and Céline de Quatrebarbes

August 2015 
What Do We Know about Mineral Resource Rent Sharing in Africa? Bertrand Laporte and Céline de Quatrebarbes

ICTD Working Paper 39

First published by the Institute of Development Studies in August 2015

(C) Institute of Development Studies 2015

ISBN: 978-1-78118-240-6

A catalogue record for this publication is available from the British Library.

All rights reserved. Reproduction, copy, transmission, or translation of any part of this publication may be made only under the following conditions:

- with the prior permission of the publisher; or

- with a licence from the Copyright Licensing Agency Ltd., 90 Tottenham Court Road, London W1P 9HE, UK,

or from another national licensing agency; or

- under the terms set out below.

This publication is copyright, but may be reproduced by any method without fee for teaching or nonprofit purposes, but not for resale. Formal permission is required for all such uses, but normally will be granted immediately. For copying in any other circumstances, or for reuse in other publications, or for translation or adaptation, prior written permission must be obtained from the publisher and a fee may be payable.

Available from:

The International Centre for Tax and Development

at the Institute of Development Studies,

Brighton BN1 9RE, UK

Tel: +44 (0) 1273606261 Fax: +44 (0) 1273621202

E-mail: info@ictd.ac.uk

Web: www.ictd/en/publications

IDS is a charitable company limited by guarantee and registered in England (No. 877338) 


\title{
What Do We Know about Mineral Resource Rent Sharing in Africa?
}

\author{
Bertrand Laporte and Céline de Quatrebarbes
}

\begin{abstract}
Summary
Governments that lack the capacity to mine resources themselves have to attract foreign direct investment. However, since resources are not renewable countries need to capture a 'fair' share of mineral resource rent to promote their development. While the sharp rise of the world prices of most minerals (in particular, gold, copper, iron and bauxite) multiplied the global turnover of the mining sector by 4.6 between 2002 and 2010, tax revenue earned by African governments from the non-renewable natural resource sector only grew by a factor of 1.15 (Mansour 2014). The sharing of mineral resource rent between governments and investors is often criticised for being unfavourable to African governments. But what do we really know about the sharing of mineral resource rent in Africa? The aim of this study is to review theoretical and empirical studies on rent sharing in Africa, and to note their limitations regarding knowledge of the actual sharing of mineral rent.
\end{abstract}

Keywords: taxation; mineral tax; resource rent tax; developing countries.

Bertrand Laporte is Associate Professor at the Université d'Auvergne, working with the Centre d'études et de recherches sur le développement international (CERDI).

Céline de Quatrebarbes is a Research Fellow at the Fondation pour les études et recherches sur le développement international (FERDI). 


\section{Contents}

Summary 3

Acknowledgements $\quad 5$

Acronyms $\quad 5$

Introduction $\quad 6$

1 Theoretical approaches: definition of rent and optimal taxation $\quad 7$

$\begin{array}{lll}1.1 & \text { Taxation of rent and economic efficiency } & 7\end{array}$

1.2 Taxation of rent and the increasing number of objectives of
taxation in developing countries

2 Empirical approaches: sharing of resource rent and available sources of information

2.1 Calculating rent: the discounted cash flow method and the modern asset pricing model 10

2.2 Rent sharing indicators 12

2.3 Review of empirical studies 13

Problems faced by empirical studies: lack of economic and
tax data

$\begin{array}{lll}3 & \text { Conclusion } & 15\end{array}$

$\begin{array}{ll}\text { Appendices } & 16\end{array}$

$\begin{array}{ll}\text { References } & 21\end{array}$

Tables

$\begin{array}{lll}\text { Table } 1 & \text { Main indicators selected in empirical literature }\end{array}$ 


\section{Acknowledgements}

The authors are grateful to Anne-Marie Geourjon, Gregoire Rota-Graziosi and ICTD member for comments on a previous draft. Any errors that remain are the responsibility of the author alone. Financial support was provided by the FERDI (LABEX IDGM+ programme) and ICTD; however, the views expressed herein do not necessarily represent those of the FERDI or ICTD.

\section{Acronyms}

$\begin{array}{ll}\text { AETR } & \text { Average effective tax rate } \\ \text { DCF } & \text { Discounted cash flow } \\ \text { EITI } & \text { Extractive Industries Transparency Initiative } \\ \text { FAD } & \text { IMF Fiscal Affairs Department } \\ \text { FARI } & \text { Fiscal Analysis of Resource Industries (FAD modelling system) } \\ \text { FERDI } & \text { Fondation pour les études et recherches sur le développement international } \\ \text { ICTD } & \text { International Centre for Tax and Development } \\ \text { IMF } & \text { International Monetary Fund } \\ \text { IRR } & \text { Internal rate of return } \\ \text { MAP } & \text { Modern asset pricing } \\ \text { METR } & \text { Marginal effective tax rate } \\ \text { NPV } & \text { Net present value }\end{array}$




\section{Introduction}

Over half of African countries produce mineral resources, and twenty of the continent's fiftyfour countries are considered to be rich in natural resources according to International Monetary Fund (IMF) criteria (IMF 2012). Although it harbours around 30 per cent of all minerals on the planet, Africa is still the continent where least use is made of mineral resources. Expenditure on exploration, however, has risen significantly over the past decade. A record was set in 2012, when Africa accounted for 17 per cent of the global exploration budget (for all minerals combined), estimated at 23.42 billion USD ${ }^{1}$ - overtaking Canada, and taking second place behind Latin America. While the Democratic Republic of the Congo is the country where expenditure on exploration is highest, West Africa has become a priority region for expenditure on searching for gold deposits. The mining sector thus presents a number of issues for the development of countries.

In most cases natural resources are public property, and the relationship between investors and governments is complex. Governments that lack the capacity to mine resources themselves have to attract foreign direct investment, but since resources are not renewable countries need to capture a fair share of mineral resource rent to aid their development. ${ }^{2}$ From the point of view of mining companies, the role of governments is to maintain a stable system that is favourable to business. The characteristics of the sector - namely irreversibility of investment and uncertainty as to whether a project will be profitable (extraction costs, sale price of the mineral extracted, etc.) - make the extraction of natural resources particularly sensitive to economic policy decisions. Decisions on taxation can have consequences that are crucial to the sector's development.

So far, mining taxation systems have adapted to changes in the price of raw materials. In the 1980 s and 1990s commodity prices were low, and governments granted companies a large number of tax and non-tax concessions for various periods of time. The mining sector has been liberalised (Campbell 2004), and African countries are developing their tax systems to attract foreign investors (Otto 1998; Land 2007). Exceptions to general law are becoming a key component of tax frameworks to reduce the tax burden of multinationals, and hence to make deposits more profitable. Between 2002 and 2012, the sharp rise of the world prices of most minerals (in particular, gold, copper, iron and bauxite) multiplied the global turnover of the mining sector by 4.6, against only 1.15 for tax revenue earned by African governments from non-renewable natural resource (Mansour, 2014). One hundred and ten nations recently amended their mining codes or are planning to do so (Otto et al. 2006 and Appendix 1). The current political context of the sector is strained: governments want to keep a more important share of the mining rent compared to previous decades, and companies fear 'holdups'3 $^{3}$ or expropriations similar to what occurred in Latin America (Daniel et al. 2010; Duncan 2006).

The development of taxation systems and tax competition between countries (Land 2007) highlight the lack of a theoretical and/or empirical consensus on the issue of how mineral

SNL Metals Economics Group: Worldwide Exploration Trends 2013.

All the big multinationals in the sector have a presence in Africa: Glencore Xstrata (iron in Mauritania, zinc in Burkina Faso, copper and cobalt in DR Congo, nickel in Tanzania, copper, cobalt and zinc in Zambia, zinc in Namibia, chromium in South Africa, etc.); Rio Tinto (aluminium in Cameroon and Ghana, bauxite in Guinea, ilmenite in Mozambique, copper and ilmenite in South Africa); Anglo American (diamonds in Botswana, Namibia and South Africa, platinum in Zimbabwe, iron and manganese in South Africa); Barrick (copper in Zambia); Newmont (gold in Ghana); AngloGold Ashanti (gold in Ghana, Guinea, Mali, Namibia, DR Congo and South Africa); and Kinross (gold in Ghana and Mauritania).

3 Opportunistic behaviour on the part of governments, which are tempted to increase the tax burden once investments have been made. 
resource rent should be shared. It now appears to be vital to build a win-win relationship, and hence to find ways of achieving a fair sharing of revenue between governments and investors (Blake and Roberts 2006; Daniel et al. 2010). The aim of this study is to review theoretical and empirical studies on rent sharing in developing countries. Re-examining the definition of resource rent and the concept of fair sharing between investors and government helps to understand the debates. Reviewing the empirical studies carried out on the subject will then make it possible to identify the existing tools used to analyse sharing of resource rent, and their weaknesses.

\section{Theoretical approaches: definition of rent and optimal taxation}

The main criticism of taxation is that it causes economic distortions which lead to loss of economic efficiency and well-being for society (Sandmo 1979). In theory, taxing up to 100 per cent of rent would not change investment and extraction decisions. A rent tax seems to be close to a neutral tax. In practice, however, there are many obstacles to apply a neutral tax instrument to the sector, including geological uncertainties and constraints on production capacity at the global level. Governments, therefore, try to create a tax system to capture a proportion of rent that is deemed to be fair, whilst encouraging private investors to explore, develop and exploit minerals. This first section examines the definition of rent and the theoretical foundations that support neutrality in its taxation, and then the tax instruments and other fees which are charged to the sector.

\subsection{Taxation of rent and economic efficiency}

The definition of rent that is most widely used today is: 'the excess of revenues over all costs of production, including those of discovery and development, as well as the normal return to capital' (IMF 2012: 5). Although the definition appears to be straightforward, rent is still difficult to understand.

Ricardo (1817) defines rent in terms of difference of agricultural land fertility. He observes that for the same level of output the least fertile land requires the greatest amount of labour or capital, and that if the price does not cover costs, production occurs at a loss and output is not brought to the market. It is, therefore, the most productive - the most fertile - land that will yield a larger profit. The rent is a long-term rent, which therefore depends on differences in fertility between land, and corresponds to the difference between the marginal cost of production and the sale price. Rent does not play a role in setting the sale price of the resource; rather, it is a result of this price-setting. According to Garnaut and Clunies Ross $(1975,1983)$, this 'differential rent' or 'pure rent' is the defining characteristic of mining industries - the fact that production conditions, which depend on the characteristics of exploitation of the resource (location, difficulty in terms of exploitation, quality of the resource, etc.), cannot be identically reproduced. This means that taxing up to 100 per cent of the differential rent generated by the sector should not alter the allocation of resources within the economy: it is a neutral tax.

From the second half of the nineteenth century onwards the concept of rent expanded to encompass all advantageous situations, which made it possible to increase the revenue of an economic operator (Khan 2000; ${ }^{4}$ Otto and Cordes 2002; Otto et al. 2006). Economic rent generally stems from private property and limited supply: contracts, patents, barriers to entry

The author distinguishes between at least six different types of rent. 
into certain markets, and so on. ${ }^{5}$ The task of valuing rent is complicated, as long-term rent can differ from short-term rent.

In the short term, production continues for as long as the sale price covers variable costs such as labour and energy (McDonald and Siegel 1985). If the market price is below the average total cost of production but equal to or greater than the average variable cost, the activity yields a short-term rent, also known as 'quasi-rent'. This quasi-rent corresponds to the difference between the revenue generated by the activity and the variable production costs - the cost of fixed factors valued at the market price (Otto et al. 2006). Quasi-rent can, however, be greater than fixed costs alone, when the revenue generated by the activity covers all variable costs and some of the fixed costs.

Mining activity comprises three stages: exploration, development and extraction (Garnaut and Clunies Ross 1983). During the first two stages (exploration and development), investments are large and constitute fixed costs which cannot be reversed by the investor. At the end of first stage, quasi-rent corresponds to expected revenue less exploration and development costs of the deposit. At the end of the second stage, quasi-rent corresponds to expected revenue less extraction cost. Total rent, which takes into account all costs associated with the various stages of the project and all revenue generated by the project, can be less than the sum of quasi-rents. Therefore, seeking to achieve neutrality of taxation entails seeking to tax, not quasi-rents, but rent valued over the entire lifetime of the project (Boadway and Keen 2010).

In a dynamic view of rent, Hotelling (1931) introduces the issue of inter-temporal management of non-renewable natural resources. How should one allocate a given quantity of resources between different periods of time, so as to maximise the utility derived from the extraction and consumption of the resource? He then defines 'scarcity rent'. The extraction of a resource generates a cost of use that corresponds to the opportunity cost of reducing stock for future use (Tilton 2004). The producer then seeks to maximise the net present value of the project - revenue less the various costs over time. The investor increases his output until the sale price covers the marginal cost of production and the opportunity cost. Valuing this opportunity cost is therefore of crucial importance, as this determines the taxable rent and alters investment and extraction decisions.

Whilst the aim of the tax system is to capture rent throughout the lifetime of the project, leaving the required minimum return on investment for the investor, inaccurate valuation of the economic rent, and hence the net present value of the project, inevitably causes economic distortions: over-exploitation or, conversely, under-exploitation of the resource (Guj 2012). The valuation of rent is subject to a certain number of constraints: knowledge of sale prices, costs and the discount rate. This information is difficult to obtain or predict, but absolutely necessary in order to apply an optimal and economically neutral tax.

\subsection{Taxation of rent and the increasing number of objectives of taxation in developing countries}

Taxation of the mining sector is essentially a delicate balancing act between the desire to attract the international investors necessary to tap into mineral resource rent, and sufficient capturing of this rent by and for the government (Laporte and Rota-Graziosi 2014). This balancing act is made particularly delicate by the characteristics of the mining sector (nonrenewable resources, irreversible investments and high uncertainty), and international competition to attract foreign technical expertise, which is limited but essential to extract the

If the factor of production is public property, which is available in an unlimited quantity and accessible to everyone, there is no rent (this applies to the environment, for example). 
resource. In practice, the competition between countries means that governments capture about 50 per cent of rent (Land 2008), and that investment depends not only on the current system for sharing resource rent, but also on the anticipated system for sharing resource rent (Boadway and Keen 2010).

Anticipation of taxation during the various stages of a project is crucial for investors. If an investor thinks that the tax system will be unfavourable to him during the production period, there is a risk that he will not make his investment (hold-up risk). However, if the tax system is changed after investments are made, the investor no longer has any choice. As long as it covers variable costs, production is economically preferable to stopping production. So as the capital invested by a company increases, the balance of power shifts from the investor to the government (Vernon 1971). Governments therefore offer significant advantages during the exploration and development phases, but can decide to take these advantages away during the extraction phase. The temptation to reduce the advantages given to a company is all the greater where the investment proves to be profitable, which is especially true during periods of high international prices (e.g. Zambia, Venezuela and Ecuador in 2008). This risk of time inconsistency in tax policy is due to the government's fundamental difficulty in identifying the optimal tax system in an uncertain environment.

Therefore, aside from the neutrality of taxation, other political, practical and administrative considerations inform the choice of instruments used to tax the mining sector (Daniel et al. 2010; Otto et al. 2006; Lund 2009; Baunsgaard 2001; Land 2008). Whether to make tax revenue secure, reduce the risks borne by the government or the investor, or facilitate tax administration, a large number of instruments are implemented in countries and help to determine the share of mineral resource rent that goes to the government (Appendix 2). Certain taxes are specific to mining activity, and others are common to all formal companies within the economy even though their tax base or rate may differ from those under the common law system (Charlet et al. 2013). Non-tax instruments supplement taxation in the capturing of mineral resource rent: royalties, production sharing, acquisition by the government of free equity, contributions to expenditure on local infrastructure, and so on. In the Democratic Republic of the Congo, the government owns 5 per cent of the capital of all mining companies that operate in the country, and has proposed increasing its stake to 35 per cent. In Burkina Faso this stake is 10 per cent, and in Mongolia the government has acquired 34 per cent of the capital in the Oyu Tolgoi project. This situation means that the government is both a regulator of the sector and a shareholder of mining companies at the same time (Allaire 2013). Every instrument for sharing resource rent has a greater or lesser impact on the exploitation of the resource.

According to the classification of Otto et al. (2006), in rem taxes (production-based taxes unit-based royalties, ad valorem or specific royalties, sales taxes which affect the variable costs of the project, import and export duties, value added tax, withholdings tax on loan interest and services, registration fees and property taxes which affect fixed costs) directly increase production costs, and thereby generate economic distortions which change investment and production decisions (Guj 2012). In personam taxes (profit-based taxes taxes on profits, additional profits taxes, withholding taxes on remitted dividends, royalty based on some measure of profit, etc.) are based on net revenue, and are therefore closer to a tax on rent. But the use of in personam taxes alone only allows for inadequate sharing of rent, due to the sensitivity of their base to transfer prices and the more or less aggressive tax optimisation strategies of private investors (Radon 2007). To the criterion of neutrality, Baunsgaard (2001) adds the criteria of risk-sharing and ease of tax administration. In rem taxes limit the risk for the government by making revenue secure from the beginning of the project, and are simple to administer. 
Identifying the tax system which allows a fair share of rent seems to depend on the degree of risk aversion of the government and private investors, and on the government's administrative capacity to collect the tax. Considering this, the optimal share of rent would therefore vary from one government to the next (and even from one ministry to the next: the Ministry of Finance versus the Ministry of Mines, Petroleum and Hydrocarbons). Given that a system needs to be stable in order to attract companies, during negotiations a tax system that makes it possible to reconcile the expectations of all stakeholders is critical.

The number of goals for sharing resource rent has increased since the 1990s. Expectations with regard to mining sector taxation go beyond mere revenue-raising, and extend to the environment (Sinkala 2009; Collier and Venables 2014), the impact of the sector on the local labour market, or economic development in its broadest sense (Bird 2014). Inter-temporal management of public funds levied from the mining sector also features prominently in the literature (Baunsgaard et al. 2012; Traoré and Djiofack Zebaze 2015). The aim is no longer to tax rent as much as possible in order to maximise public funds without altering the production chain, but to maximise social well-being. The framework of the tax system is thus moving away from the pursuit of economic neutrality, and demonstrates the importance that is attached to each objective by mining governments. Every system has consequences for project life and hence the sharing of rent between governments and investors (Cawood 1999; Cordes 1995; Otto et al. 2006). The increase in the number of objectives for mining taxation is giving rise to a complex web of taxes, making it difficult to assess the sharing of rent and its economic impact.

\section{Empirical approaches: sharing of resource rent and available sources of information}

The sharing of mineral resource rent between governments and investors is often criticised for being unfavourable to African governments. However, few studies put figures on this phenomenon. After a description of the two dominant methods of valuing rent, the main indicators used to assess tax systems are presented. Shafiee et al. (2009) propose a literature review of empirical studies that use these two methods, but do not address sharing of resource rent. Smith (2013) proposes a review of literature focusing on the sharing of mineral resource rent, and highlights the importance of modelling choices on the result.

\subsection{Calculating rent: the discounted cash flow method and the modern asset pricing model}

The net present value (NPV) that should be generated during the lifetime of a project depends on annual mineral output, exploration and development costs, capital costs and extraction costs, the lifetime of the project, the sale price, and the discount rate that is associated with the project and incorporates the risk (Guj and Garzon 2007). Two main methods are used to determine NPV: the discounted cash flow (DCF) method and the modern asset pricing (MAP) model.

Discounted cash flow (DCF) method. If a project is certain and without risks, the discount rate is the opportunity cost of the capital. If cash flow is uncertain and risky, the discount rate is made up of the opportunity cost of the capital and the premium that compensates the risk assumed by the investor. This risk may be project-specific and/or country-specific. Most models incorporate a single cash flow, but allow for sensitivity analyses that consider different cost or price profiles. Monte Carlo simulations are often performed in order to determine a probability distribution for each uncertain project variable and thereby obtain 
different cash flows (Bohren and Schilbred 1980). Even at the lowest anticipated price, a mining project should be able to break even (Crowson 1998). The following are needed to create a DCF model: (i) forecasts for the price of the mineral over the entire duration of the project, (ii) a valuation of costs, making it possible to calculate the revenue from the project, and (iii) the discount rate of the project after tax.

Several authors underline the limitations of this method (Bradley 1998; Daniel et al. 2010; Mackie-Mason 1990; Samis et al. 2007; Smith 2013; Salahor 1998). On the one hand, it requires perfect knowledge of the economic indicators that are involved in calculating NPV, and, on the other hand, it entails knowing the risk associated with each stage of the project. If this is not the case, the modeller most often assumes uniform risk, which is not necessarily realistic for long-term projects whose risk decreases over time. Finally, these models are arithmetical and non-behavioural, which limits the scope of the results and assumes that taxation is neutral in respect of production and investment decisions (Smith 2013). Finally, the model does not take account of managerial risk - the possibility that the mine may be abandoned before the end of its life cycle, or that work may be suspended temporarily (Smith and McCardle 1998).

Modern asset pricing (MAP) model. In order to take different risk profiles into account, an alternative to the DCF model is to calculate the certainty equivalent. Brennan and Schwartz (1985) were the first to use this method to value natural resource exploitation projects (Grinblatt and Titman 2002; Laughton 1998). This method involves determining the cash flow that the investor is willing to receive without risk, and comparing it with expected future cash flows. The investor does not mind whether he receives this certainty equivalent or the uncertain future cash flow. The net present value of the project is then defined as the sum total of certainty equivalent flows discounted at the risk-free rate. The MAP model is an elementary form of the 'real option value' ${ }^{6}$ model, which takes into account, within a stochastic forecasting model, the price dynamics of the mineral and incorporates the interaction between the uncertainty as to price and the risk in terms of the project's value. Several price change models exist, according to the type of mineral that is studied (Salahor 1998; Baker et al. 1998). In 1996, Laughton used the MAP method to assess the financial structure of a mining project. According to Moel and Tufano (2002), companies are increasingly using the MAP method to make their own forecasts. To create this type of model (Guj and Garzon 2007), ${ }^{7}$ it is necessary to: (i) choose the stochastic price change forecasting model, (ii) determine the price risk due to uncertainty regarding the price of the mineral over the period and its discount rate, ${ }^{8}$ and (iii) build the cash flow model for the project whilst taking account of the prices predicted by the forecasting model and information concerning the costs of the project. The main difficulty of the MAP method lies in identifying the right risk profile. Most of the time only the price is regarded as uncertain, and the costs of the project are considered to be known. It is therefore necessary to obtain information concerning forecasts for the price of commodities on the financial market. ${ }^{9}$ Bradley (1998) shows that valuing net revenue using the DCF method or the MAP method gives different results, and generates revenue flows with different profiles.

Both methods have advantages and disadvantages. However, in both cases the two crucial points in calculating rent are having access to economic information concerning the project, and testing different risk profiles (Commonwealth Secretariat and ICMM 2009). Only after

By comparison with the real option value model, only managerial flexibility, i.e. the possibility that the mine will be abandoned before it reaches the end of its life cycle or that activity will temporarily be suspended, is not taken into account (Podda Abouna 2014).

Quoted in Podda Abouna et al. (2014).

The discount rate is the risk-free interest rate, because risk is already taken into account in the stochastic model. Depending on the mineral, the London Metal Exchange, KITCO or the New York Mercantile Exchange websites. 
evaluating the NPV for each project developed in the country is it possible to measure the sharing of rent between governments and investors, and its effect on investment decisions.

\subsection{Rent sharing indicators}

Several indicators are used in the literature to assess tax systems in the mining sector (Daniel et al. 2008; Otto et al. 2006; Boadway and Keen 2010; IMF 2012). Only the ones that are most widely used in empirical studies are presented here (see Table 1). The investor is interested in profitability indicators, whereas the government seeks to measure its share of rent.

Table 1 Main indicators selected in empirical literature

\begin{tabular}{|c|c|c|}
\hline Agent & Objective & Indicator \\
\hline \multirow{3}{*}{ Investor } & Neutrality & $\begin{array}{l}\text { Marginal effective tax rate (METR) } \\
\text { Breakeven price }\end{array}$ \\
\hline & Profitability & $\begin{array}{l}\text { Internal rate of return (IRR) on the project } \\
\text { Payback period }\end{array}$ \\
\hline & Identification of risks & Coefficient of variation of Net Present Value and IRR \\
\hline \multirow{2}{*}{ Government } & Tax revenue & $\begin{array}{l}\text { Average effective tax rate (AETR) } \\
\text { Expected government revenue }\end{array}$ \\
\hline & Identification of risks & $\begin{array}{l}\text { Time profile of government revenue } \\
\text { Coefficient of variation in expected tax revenue }\end{array}$ \\
\hline
\end{tabular}

The indicators chosen by companies measure the profitability of their investment over the entire duration of a project. The investor's share of the rent corresponds to the discounted value of net cash flows after tax. The profitability of the investment is valued by the internal rate of return (IRR) on the investment, which corresponds to the discounted rate for which the sum total of cash flows is nil. In principle, investment only occurs if the opportunity cost of the capital is lower than the internal rate of return on the project. The marginal effective tax rate (METR), for which a proxy can be calculated from the IRR before and after tax, captures the impact of the tax system on the decision to invest. For a given level of project profitability required by the investor, it measures the additional profitability that the project must yield in order to cover tax liabilities. It may be regarded as an indicator of tax system neutrality. According to Brealey and Myers (2005), the IRR calculation method does not make it possible to take account of variability of the opportunity cost of capital over time, and makes it difficult to compare projects with each other. Empirical studies often compare, for the same project, the impact of different tax systems on the sharing of rent from a single project.

The indicator that is most commonly used to measure the share of rent captured by the government is the average effective tax rate (AETR). AETR is the ratio of the NPV of government revenue and the NPV of project pre-tax net cash flows. ${ }^{10}$ All taxes specific to the sector, such as those under the General Taxation Code and other charges and fees, must be considered. The AETR makes it possible to assess the distribution of the tax burden between companies, in order to assess fairness in the treatment of companies (Fullerton and King 1984; Johnston 2003) and make international comparisons (Daniel et al. 2010; Charlet et al. 2013). The share of government revenue in total project benefits, measured by the ratio of tax revenue paid by the investor and discounted net cash flow less the initial investment, makes it possible to assess the sensitivity of government revenue to variation in prices

10 Several calculation methods are used in the literature (Otto et al. 2000; Devereux and Griffith 2003). 
and/or costs, and hence how progressive the tax system is. ${ }^{11} \mathrm{~A}$ progressive tax system can encourage the government to develop the sector, but a regressive system can enable the government to guarantee a minimum level of tax revenue (Brewer et al. 1989). Calculating the coefficient of variation in the proportion of rent received by the government for a given revenue distribution makes it possible to ascertain the possible variation in government revenue - that is, the risk assumed by the government.

\subsection{Review of empirical studies}

Few empirical studies quantify the sharing of rent between investors and governments in the natural resource sector (see Appendix 3). Oil is the sector that has been studied the most (Blake and Roberts 2006; Daniel et al. 2008; Tordo 2007), followed by gold (inter alia Brewer et al. 1989; Otto et al. 2006). In the great majority of cases studies are carried out on hypothetical mining projects, and the authors apply different tax systems to the project (Blake and Roberts 2006; Brewer et al. 1989), or only change the base for one tax in order to determine the impact on investment indicators or the capturing of rent by the government. Special attention has been paid to different types of royalties (Otto et al. 2006; Daniel et al. 2010). It is rare for simulations to analyse the overall framework of a mining tax system for a single country. Charges and fees are often dealt with secondarily to tax instruments (Blake and Roberts 2006), which makes the calculation for sharing of resource rent incomplete. The aforementioned indicators are commonly used by the authors to combine the operation of a tax with an objective of neutrality of taxation or government revenue. The most common method is discounted cash flow, combined with ad hoc sensitivity analyses. Few studies take into account the effects of interaction between the mining sector and the rest of the economy (Thomas 2010). Finally, it is important to note that there has been very little analysis of the tax systems in developing countries - more specifically, in African countries.

The IMF made efforts to improve the knowledge of states in the area of rent-sharing. The Fiscal Analysis of Resource Industries (FARI) model is now used in countries receiving IMF technical assistance in the mining and oil sectors. However, the basic economic data, the tax information and the results of rent sharing studies are not publicly available for at least two reasons: (1) technical assistance reports are compiled from confidential data; and (2) they are the property of the local Ministry of Finance in countries receiving technical assistance, and may be published only with their agreement. Furthermore, some African countries that are rich in natural resources do not have specific technical assistance.

This literature review shows that it is currently very difficult to ascertain the actual sharing of rent between African governments and investors in a standardised manner. Economic data on projects is either not widely available or difficult for researchers to use, which forces them to create hypothetical mine projects. However, as Otto et al. (2006) and all of the sensitivity analyses in this literature point out, tax system evaluation indicators are sensitive to the characteristics of mines and changes in their economic environment. In addition no maps are available, making regional or international comparisons difficult. In the current context of renegotiating mining codes, creating an innovative database that allows standardised assessment of the sharing of mineral resource rent in Africa would appear, in the light of the studies analysed, to be very important.

\subsection{Problems faced by empirical studies: lack of economic and tax data}

Ascertaining how rent is shared between governments and investors requires the capacity to calculate the NPV that should be generated for each project. Whichever method is used, the following must be known: the annual production of the mineral, the capital costs and

11 This particular indicator is still under revision in the IMF's Fiscal Affairs Department. 
operating costs for each stage of the project, its lifetime, the sale price and the associated discount rate. The fact that few empirical studies have been carried out on mining projects clearly illustrates the difficulty of obtaining and processing this information. Economic data on industrial mining companies (feasibility studies, financial statements and technical reports) is available online for companies listed on stock exchanges in Canada, the USA, Australia and the UK. Data in feasibility studies (forecasts) can be compared with information held in activity reports (implementation). It may therefore be difficult, but not impossible, to create the economic part of the database.

To measure the sharing of NPV between investors and the government, it is also necessary to know all the tax instruments and other fees charged on the sector. None of the existing economic databases contains all this information on the mining sector. The FERDI database presents the tax revenue levied from the sector for forty-one countries in sub-Saharan Africa over the period 1980-2010 (Mansour 2014). The countries listed in the database make up over 95 per cent of the countries that the World Bank describes as being rich in natural resources. Revenue from oil and gas and that from mining activities are combined, but few countries are rich in both hydrocarbons, and minerals other than hydrocarbons. Revenue collected from activities in the mining, oil and gas sectors is separated from that collected from other activities. The 'taxes on non-renewable natural resources' category combines the tax revenue levied from extractive industries (corporation tax, royalties and also profitsharing, dividends received on equity held in state-owned enterprises, and dividends and other investment income received on holdings acquired directly by the government in extractive industries). The ICTD database lists the revenue levied from the natural resource sector, and breaks it down by type of tax: income taxes, corporation taxes, indirect taxes (mainly export taxes) and non-tax revenue (Prichard et al. 2014). These two databases propose a sector-based approach, which limits the opportunity to ascertain the sharing of rent between governments and investors for a mineral, much less analyse its determining factors. The Extractive Industries Transparency Initiative (EITI) promotes accountable management of natural resources, by making public the revenue paid by firms. The database is broken down by country and by sector (oil/gas and mining). However, the EITI objective is not the evaluation of sharing of rent, and does not allow this to be done.

To measure the sharing of rent, it is necessary to list the tax codes, mining codes, customs codes and mining agreements that are in force in Africa. Charlet et al. (2013) list the taxes levied in French-speaking African countries (see Appendix 2), which would make it possible to recalculate the revenue collected from each project and hence the sharing of rent.

Based on this tax information and project economic data, the expected sharing of rent between governments and investors can be calculated for each mining project. It could be possible to compare the theoretical tax revenue with the effective tax revenue in the EITI database. The gap between expected revenue and achievement can be explained by a change in operating conditions (geology, costs and resource prices), failure of tax administration, or tax optimisation practices of mining companies.

\section{Conclusion}

The aim of this study is to review theoretical and empirical studies on the sharing of resource rent in developing countries in order to identify the difficulties encountered in conducting this type of exercise, so that tools to mitigate them can subsequently be proposed.

Having reviewed the theoretical approaches to the valuation of rent on a microeconomic level, we find that mineral resource rent is a concept that is difficult to understand and 
measure: rent can change as a project moves from one phase to the next, and risk and the discount rate of the resource must be taken into account. The most widely-accepted definition of rent relates to the calculation of the net present value of a project - 'the excess of revenues over all costs of production, including those of discovery and development, as well as the normal return to capital' (IMF 2012: 5). However, the possibility of capturing tax revenue in an economically neutral way can only be guaranteed if governments have the capacity to value the economic rent of a project.

Due to the difficulty of obtaining all the information necessary to calculate mineral resource rent, governments are increasing the number of tax instruments, charges and fees in order to capture a share of resource rent that they deem fair, but which ultimately depends strictly on the objectives that they have set for themselves. This is why different indicators are used in the literature to assess tax systems in the natural resource sector according to the objectives of governments and investors. A review of empirical studies shows that few studies are conducted in developing countries, and African countries in particular, and that they are mainly based on hypothetical projects. Knowledge of the actual distribution of rent between investors and governments is scant, and knowledge of its determining factors is even more so.

The distribution of mineral resource rent in Africa cannot be analysed without access to figures and transparent, standardised information. The creation of a rent-sharing database will allow in-depth research into the value of the sector's tax potential, the tax optimisation practices of multinationals and the knock-on effects that the mining sector has on the rest of the economy; this is currently not possible given the actual knowledge available on sharing of resource rent in Africa. 
Appendix 1 Renegotiation of contracts in Africa (as at 30 September 2013)

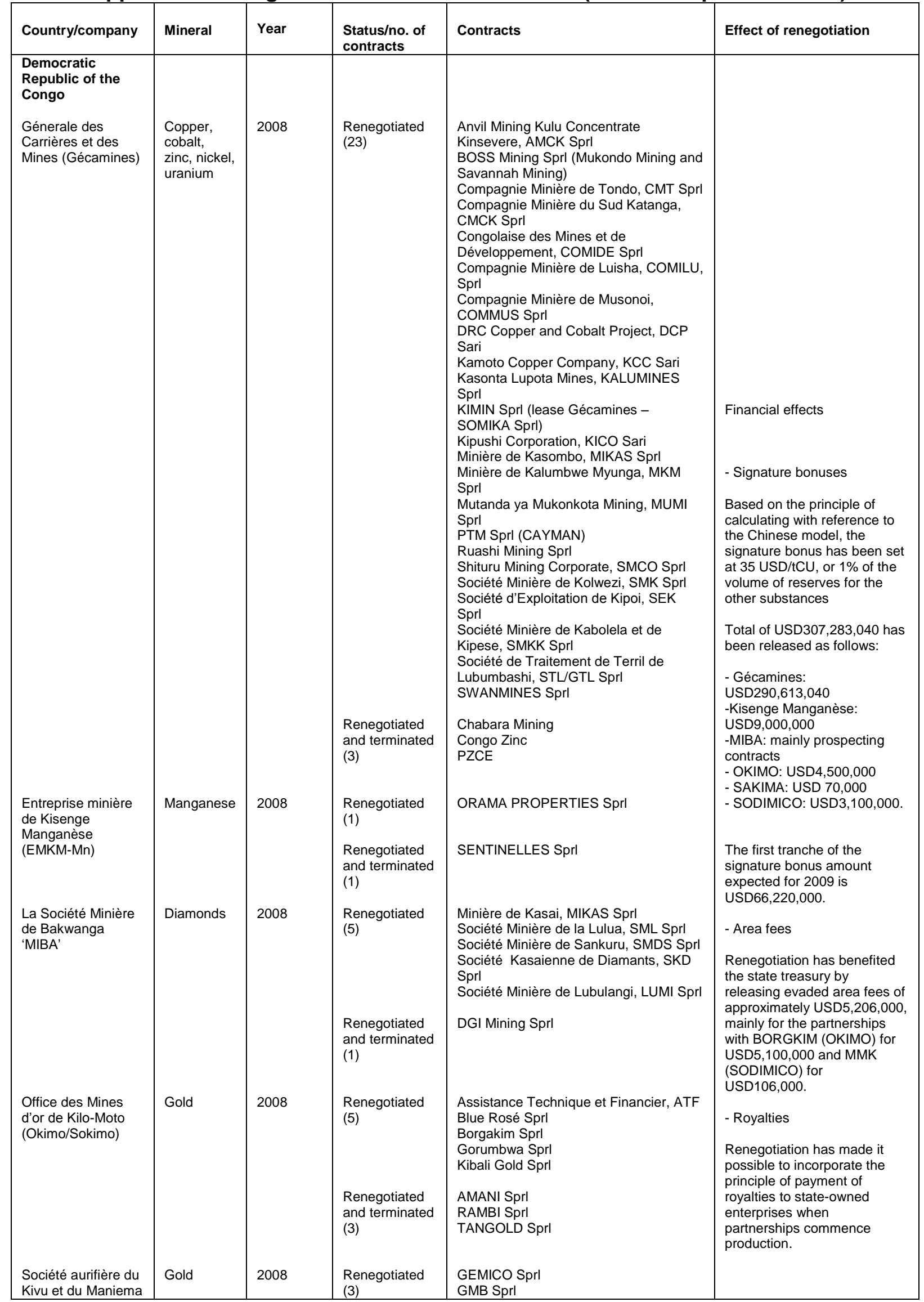




\begin{tabular}{|c|c|c|c|c|c|}
\hline $\begin{array}{l}\text { Société de } \\
\text { Développement } \\
\text { Industriel et Minier } \\
\text { du Congo } \\
\text { (Sodimico) }\end{array}$ & Copper & 2008 & $\begin{array}{l}\text { Renegotiated } \\
\text { and terminated } \\
\text { (3) } \\
\text { Renegotiated } \\
\text { (2) } \\
\text { Renegotiated } \\
\text { and terminated } \\
\text { (3) }\end{array}$ & $\begin{array}{l}\text { DFSA Sprl } \\
\text { CAR Sprl } \\
\text { COCO Mining Sprl } \\
\text { SOL Sprl } \\
\text { MMK Sari } \\
\text { Long Fei Sprl } \\
\text { KGHM Sprl } \\
\text { MUYAFA Sprl } \\
\text { SOCOMIE Sprl }\end{array}$ & \\
\hline Guinea & & & & & \\
\hline $\begin{array}{l}\text { Rio Tinto } \\
\text { BSG Resources }\end{array}$ & $\begin{array}{l}\text { Iron } \\
\text { Iron }\end{array}$ & $\begin{array}{l}2011 \\
\mathrm{n} / \mathrm{a}\end{array}$ & $\begin{array}{l}\text { Renegotiated } \\
\text { (1) } \\
\text { Intention to } \\
\text { renegotiate }\end{array}$ & Simfer SA & $\begin{array}{l}\text { Settlement agreement: } \\
\text { government-owned equity, } \\
\text { granting of presidential } \\
\text { decrees, taxation and royalty } \\
\text { and infrastructure }\end{array}$ \\
\hline RUSAL & Bauxite & $\mathrm{n} / \mathrm{a}$ & $\begin{array}{l}\text { Intention to } \\
\text { renegotiate }\end{array}$ & Friguia & \\
\hline $\begin{array}{l}\text { Liberia } \\
\text { Arcellor-Mittal }\end{array}$ & Iron & 2005 & $\begin{array}{l}\text { Renegotiated } \\
\text { (1) }\end{array}$ & & $\begin{array}{l}\text { The Indian giant set prices of } \\
\text { the mineral itself. After a year } \\
\text { of negotiation, the group is } \\
\text { now following market prices; } \\
\text { the tax exemption has been } \\
\text { ended. }\end{array}$ \\
\hline $\begin{array}{l}\text { Sierra Leone } \\
\text { African Minerals } \\
\text { London Mining }\end{array}$ & $\begin{array}{l}\text { Iron } \\
\text { Iron }\end{array}$ & $\begin{array}{l}2011 \\
2011\end{array}$ & $\begin{array}{l}\text { Renegotiated } \\
\text { (1) } \\
\text { Renegotiated } \\
\text { (1) }\end{array}$ & $\begin{array}{l}\text { Tonkolili Iron } \\
\text { Marampa }\end{array}$ & $\begin{array}{l}\text { Replaces the clause in the } \\
\text { London Mining contract } \\
\text { concerning a ten-year break } \\
\text { for the company which } \\
\text { reduced its tax rate from } \\
37.5 \% \text { to } 6 \% \text { increasing in } \\
\text { stages to } 30 \% \text {. Source: 'The } \\
\text { revised London Mining } \\
\text { Agreement' } \\
\text { <http//www.christianaid.org.uk } \\
\text { /lmages/sierra-leone-mining- } \\
\text { briefing.pdf> }\end{array}$ \\
\hline $\begin{array}{l}\text { Ghana } \\
\text { South Africa's } \\
\text { AngloGold Ashanti } \\
\text { Newmont of } \\
\text { Greenwood }\end{array}$ & $\begin{array}{l}\text { Gold } \\
\text { Gold }\end{array}$ & $\begin{array}{l}\mathrm{n} / \mathrm{a} \\
\mathrm{n} / \mathrm{a}\end{array}$ & $\begin{array}{l}\text { Intention to } \\
\text { renegotiate on } \\
\text { the part of the } \\
\text { government } \\
\text { but not } \\
\text { accepted by } \\
\text { the company }\end{array}$ & $\mathrm{n} / \mathrm{a}$ & $\begin{array}{l}\text { In } 2010 \text { Ghana changed the } \\
\text { mining royalty rate to a fixed } \\
\text { rate of } 5 \% \text { from a variable } \\
\text { rate of } 3-6 \% \text {. AngloGold } \\
\text { Ashanti and Newmont of } \\
\text { Greenwood have stability } \\
\text { agreements set at } 3 \% \text {. The } \\
\text { government wants to } \\
\text { renegotiate the stability } \\
\text { agreement. }\end{array}$ \\
\hline $\begin{array}{l}\text { Central African } \\
\text { Republic } \\
\text { AREVA }\end{array}$ & Uranium & 2008 & $\begin{array}{l}\text { Renegotiated } \\
\text { (1) }\end{array}$ & Bakouma & $\begin{array}{l}\text { In } 2007 \text { Areva bought UraMin, } \\
\text { a Canadian uranium } \\
\text { extraction company which at } \\
\text { that time owned the Bakouma } \\
\text { concession. The CAR } \\
\text { protested and demanded that } \\
\text { Areva renegotiate the } \\
\text { contract. In August } 2008 \text {, } \\
\text { Areva agreed to pay USD40 } \\
\text { million over five years, to } \\
\text { develop the country's } \\
\text { infrastructure and to employ } \\
900 \text { local workers at the peak } \\
\text { of its activity. At the end of } \\
2009 \text {, the CAR demanded } \\
\text { nearly FCFA2 billion (USD } 4 \\
\text { million) in taxes and royalties } \\
\text { in relation to the transfer of } \\
\text { UraMin. }\end{array}$ \\
\hline Axmin & Gold & $2009 / 2010$ & $\begin{array}{l}\text { Renegotiated } \\
\text { (1) }\end{array}$ & Bambari/Ouaka & $\begin{array}{l}\text { Axmin requested an } \\
\text { exploration permit in March } \\
2009 \text { but only received one in } \\
\text { August } 2010 \text { after agreeing to } \\
\text { pay a bonus of USD } 11 \text { million } \\
\text { and delivering three } 4 \times 4 \\
\text { vehicles. }\end{array}$ \\
\hline
\end{tabular}

Source: Charlet et al. (2013). 
Appendix 2 Examples of tax systems in French-speaking Africa

\begin{tabular}{|c|c|c|c|c|c|c|}
\hline Country & Legislation & $\begin{array}{l}\text { Mining royalty (\% of } \\
\text { total turnover) }\end{array}$ & $\begin{array}{l}\text { Government } \\
\text { stake }\end{array}$ & Profit tax & $\begin{array}{l}\text { Minimum } \\
\text { lump sum } \\
\text { tax }\end{array}$ & $\begin{array}{l}\text { Tax on } \\
\text { income } \\
\text { from } \\
\text { transferable } \\
\text { securities }\end{array}$ \\
\hline $\begin{array}{l}\text { Burkina } \\
\text { Faso }\end{array}$ & $\begin{array}{l}\text { Law no. 031- } \\
2003 / \text { AN of } 8 \text { May } \\
2003 \\
\text { Decree no. 2005- } \\
\text { 048/PRES of } 3 \\
\text { February } 2005 \\
\text { Decree no. } 2005- \\
\text { 682/PRES/PM/MCE } \\
\text { /MFB of } 30 \\
\text { December } 2005\end{array}$ & $\begin{array}{l}7 \% \text { - diamonds and } \\
\text { precious stones } \\
4 \% \text { - base metals and } \\
\text { other mineral } \\
\text { substances } \\
3 \% \text { - industrial gold and } \\
\text { precious metals } \\
3 \% \text { - artisanally mined } \\
\text { gold, and tax relief of } \\
100 \text { CFA francs per } \\
\text { gram is granted before } \\
\text { the rate is applied }\end{array}$ & $\begin{array}{l}10 \% \text { free } \\
\text { equity } \\
\text { interest }\end{array}$ & $\begin{array}{l}\text { Exemption } \\
\text { during } \\
\text { exploration } \\
\text { phase } \\
\text { Rate reduced } \\
\text { by } 10 \\
\text { percentage } \\
\text { points during } \\
\text { production } \\
\text { phase }\end{array}$ & $\begin{array}{l}0.5 \% \\
\text { Exemption } \\
\text { during } \\
\text { exploration } \\
\text { phase } \\
\text { Exemption } \\
\text { for } 7 \text { years } \\
\text { during } \\
\text { production } \\
\text { phase }\end{array}$ & $\begin{array}{l}12.5 \% \\
\text { Exemption } \\
\text { during } \\
\text { exploration } \\
\text { phase } \\
\text { Rate halved } \\
\text { during } \\
\text { production } \\
\text { phase } \\
(6.25 \%)\end{array}$ \\
\hline Cameroon & $\begin{array}{l}\text { Law no. } 2010 / 011 \\
\text { of } 29 \text { July } 2010 \\
\text { Law no. } 001-2001 \\
\text { of } 16 \text { April } 2001 \\
\text { Decree no. } \\
2002 / 648 / P M \text { of } 26 \\
\text { March } 2002\end{array}$ & $\begin{array}{l}\% \text { - Precious stones: } \\
\text { (diamonds, emeralds, } \\
\text { rubies, sapphires) } \\
3 \% \text { - Precious metals: } \\
\text { (gold, platinum, etc.) } \\
2.5 \% \text { - Base metals and } \\
\text { other mineral } \\
\text { substances } \\
2 \% \text { - Geothermal } \\
\text { deposits, source water, } \\
\text { mineral and thermal } \\
\text { mineral water }\end{array}$ & $\begin{array}{l}10 \% \text { free } \\
\text { equity } \\
\text { interest + } \\
\text { right to } \\
\text { acquire an } \\
\text { additional } \\
\text { stake in cash } \\
\text { up to a total } \\
\text { limit that } \\
\text { cannot } \\
\text { exceed } 20 \%\end{array}$ & $\begin{array}{l}35 \%(+3.5 \% \\
\text { by way of } \\
\text { Additional } \\
\text { Municipal } \\
\text { Taxes, } \\
\text { making an } \\
\text { effective rate } \\
\text { of } 38.5 \%) \\
\text { Exemption } \\
\text { during } \\
\text { exploration } \\
\text { phase }\end{array}$ & & $\begin{array}{l}15 \%+1.5 \% \\
\text { by way of } \\
\text { Additional } \\
\text { Municipal } \\
\text { Taxes, } \\
\text { making an } \\
\text { effective } \\
\text { rate of } \\
16.25 \% \\
\text { Exemption } \\
\text { during } \\
\text { exploration } \\
\text { phase }\end{array}$ \\
\hline DR Congo & $\begin{array}{l}\text { Law no. } 007 / 2002 \\
\text { of } 11 \text { July } 2002 \\
\text { Decree no. } \\
038 / 2003 \text { of } 26 \\
\text { March } 2003 \\
\text { Inter-ministerial } \\
\text { order no. } \\
\text { 3154/CAB.MIN/MIN } \\
\text { ES/01/2007 and no. } \\
031 / C A B . M I N / F I N A \\
\text { NCES/2007 of } 09 \\
\text { August } 2007\end{array}$ & $\begin{array}{l}0 \% \text { - widely-used } \\
\text { building materials } \\
0.5 \% \text { - iron and ferrous } \\
\text { metals } \\
1 \% \text { - industrial minerals } \\
1 \% \text { - solid hydrocarbons } \\
\text { and other substances } \\
\text { not specified } \\
2 \% \text { - non-ferrous metals } \\
2.5 \% \text { - precious metals } \\
4 \% \text { - precious stones }\end{array}$ & No & $35 \%$ & & $20 \%$ \\
\hline $\begin{array}{l}\text { Côte } \\
\text { d'Ivoire }\end{array}$ & $\begin{array}{l}\text { Law no. 95-553 of } \\
17 \text { July } 1995 \\
\text { Ordinance no. 96- } \\
600 \text { of } 9 \text { August } \\
1996 \\
\text { Decree no. } 96-634 \\
\text { of } 09 \text { August }\end{array}$ & $\begin{array}{l}3 \% \text { - for gold, diamonds, } \\
\text { precious stones and } \\
\text { metals } \\
2.5 \% \text { - for base metals }\end{array}$ & $\begin{array}{l}10 \% \text { free } \\
\text { equity } \\
\text { interest }\end{array}$ & $\begin{array}{l}25 \% \text { (or 20\% } \\
\text { for } \\
\text { companies } \\
\text { whose } \\
\text { turnover is } \\
\text { less than } 1 \\
\text { billion CFA } \\
\text { francs and } \\
\text { individual } \\
\text { entrepreneurs }\end{array}$ & & $\begin{array}{l}12 \% \text { - } \\
\text { General-law } \\
\text { rate } \\
18 \% \text { - Profit } \\
\text { distributions } \\
\text { which are } \\
\text { exempt from } \\
\text { profit tax or } \\
\text { have not } \\
\text { been taxed } \\
\text { at the } \\
\text { general-law } \\
\text { rate } \\
10 \% \text { - } \\
\text { Dividends of } \\
\text { companies } \\
\text { listed on the } \\
\text { stock } \\
\text { exchange } \\
2 \% \text { - Income } \\
\text { from bonds } \\
\text { that are } \\
\text { redeemable } \\
\text { within at } \\
\text { least } 5 \text { years }\end{array}$ \\
\hline
\end{tabular}

Source: Charlet et al. (2013) 


\section{Appendix 3 Empirical studies on the sharing of rent}

\begin{tabular}{|c|c|c|c|c|c|c|}
\hline Authors & Minerals & Methods & $\begin{array}{l}\text { Economic } \\
\text { data }\end{array}$ & Tax system simulation & $\begin{array}{l}\text { Sensitivity } \\
\text { analysis }\end{array}$ & Indicators \\
\hline $\begin{array}{l}\text { Blake } \\
\text { and } \\
\text { Roberts } \\
\text { (2006) }\end{array}$ & Oil & MAP & $\begin{array}{l}\text { Hypothetical } \\
\text { project }\end{array}$ & $\begin{array}{l}\text { Simulation: Comparison of national tax } \\
\text { systems } \\
\text { Alberta: Taxes and royalty } \\
\text { Papua New Guinea: Resource rent tax } \\
\text { Sao Tome: Joint Development Zone } \\
\text { Tanzania: Production sharing and } \\
\text { resource rent tax } \\
\text { Trinidad: Production sharing only }\end{array}$ & $\begin{array}{l}\text { Monte Carlo } \\
\text { simulation }\end{array}$ & $\begin{array}{l}\text { Net present value } \\
\text { before tax } \\
\text { Net present value } \\
\text { after tax } \\
\text { Tax distortion } \\
\text { index }\end{array}$ \\
\hline $\begin{array}{l}\text { Brewer et } \\
\text { al. (1989) }\end{array}$ & Gold & DCF & $\begin{array}{l}\text { Hypothetical } \\
\text { project }\end{array}$ & $\begin{array}{l}\text { Simulation: Comparison of national tax } \\
\text { systems } \\
\text { Canada, USA, Australia, Brazil, Chile, } \\
\text { Indonesia, Papua New Guinea, Peru, } \\
\text { South Africa, Zambia }\end{array}$ & $\begin{array}{l}\text { Ad hoc } \\
\text { change: } \\
\text { profitability of } \\
\text { project, } \\
\text { inflation, price } \\
\text { cycle }\end{array}$ & Effective tax rate \\
\hline $\begin{array}{l}\text { Daniel et } \\
\text { al. (2008) }\end{array}$ & Oil & DCF & $\begin{array}{l}\text { Three } \\
\text { hypothetical } \\
\text { projects with } \\
\text { different price } \\
\text { and cost } \\
\text { structures }\end{array}$ & $\begin{array}{l}\text { Initial situation: Royalty with deduction } \\
\text { of } 65 \% \text { of capital costs, Mozambique. } \\
\text { Simulation: (i) deduction increased to } \\
90 \% \text { plus production sharing, (ii) } \\
\text { Simulation of other international systems: } \\
\text { Nigeria, Angola, Eq. Guinea, Mauritania, } \\
\text { Ghana, Madagascar, Mozambique, } \\
\text { Namibia, Sierra Leone then Norway, UK, } \\
\text { Colombia, Australia, East Timor, Peru }\end{array}$ & $\begin{array}{l}\text { Ad hoc } \\
\text { change: sale } \\
\text { price and } \\
\text { discount rate }\end{array}$ & $\begin{array}{l}\text { Time profile of } \\
\text { revenue } \\
\text { Project pre-tax } \\
\text { NPV } \\
\text { Contractor NPV } \\
\text { Payback period } \\
\text { Government } \\
\text { revenue } \\
\text { AETR, } \\
\text { Breakeven Price } \\
\text { and METR } \\
\text { Government } \\
\text { share of total } \\
\text { benefits } \\
\text { Coefficient ov } \\
\text { variation of } \\
\text { government } \\
\text { revenue } \\
\text { Post Tax IRR, } \\
\text { coefficient of } \\
\text { variation of IRR }\end{array}$ \\
\hline $\begin{array}{l}\text { Devereux } \\
\text { and } \\
\text { Griffith } \\
(2003)\end{array}$ & Industry & DCF & $\begin{array}{l}\text { Hypothetical } \\
\text { project }\end{array}$ & $\begin{array}{l}\text { Simulation: Harmonisation of nominal } \\
\text { tax rates within the European Union: UK, } \\
\text { Germany, France }\end{array}$ & No & $\begin{array}{l}\text { Net present value } \\
\text { before tax } \\
\text { Net present value } \\
\text { after tax } \\
\text { Average effective } \\
\text { tax rate } \\
\text { Marginal effective } \\
\text { tax rate }\end{array}$ \\
\hline $\begin{array}{l}\text { Lund } \\
\text { (1992) }\end{array}$ & Oil & MAP & $\begin{array}{l}\text { Hypothetical } \\
\text { project }\end{array}$ & $\begin{array}{l}\text { Initial situation: Norway: Royalty, } \\
\text { income tax, corporate tax, special oil tax, } \\
\text { witholding on dividends, capital tax on } \\
\text { book value of assets } \\
\text { Simulation: Zero royalty, production } \\
\text { allowance, 'uplift' allowance abandoned } \\
\text { for specific costs, depreciation allowed } \\
\text { from the date of investment, reduction in } \\
\text { rate of tax on petroleum }\end{array}$ & $\begin{array}{l}\text { Monte Carlo } \\
\text { simulation }\end{array}$ & Net present value \\
\hline $\begin{array}{l}\text { Otto et al. } \\
(2006)\end{array}$ & $\begin{array}{l}\text { Gold, } \\
\text { copper, } \\
\text { bauxite }\end{array}$ & DCF & $\begin{array}{l}\text { Three } \\
\text { hypothetical } \\
\text { projects with } \\
\text { different price } \\
\text { and cost } \\
\text { structures }\end{array}$ & $\begin{array}{l}\text { Initial situation: national tax system, } \\
\text { Chile, South Africa } \\
\begin{array}{l}\text { Simulation: Eight different bases for } \\
\text { mining royalties }\end{array}\end{array}$ & $\begin{array}{l}\text { Ad hoc } \\
\text { change: } \\
\text { operating } \\
\text { costs, capital } \\
\text { costs, sale } \\
\text { price }\end{array}$ & $\begin{array}{l}\text { Internal rate of } \\
\text { return of the } \\
\text { project } \\
\text { Investor's share } \\
\text { of rent } \\
\text { Average effective } \\
\text { tax rate (AETR) } \\
\text { Government } \\
\text { revenue }\end{array}$ \\
\hline
\end{tabular}




\begin{tabular}{|c|c|c|c|c|c|c|}
\hline $\begin{array}{l}\text { Podda } \\
\text { Abouna } \\
\text { et al } \\
(2014)\end{array}$ & Gold & MAP & $\begin{array}{l}\text { Existing } \\
\text { project } \\
\text { Canada }\end{array}$ & $\begin{array}{l}\text { Initial situation: Profit-based royalty, } \\
\text { Canada } \\
\text { Simulation: Ad valorem royalty and } \\
\text { super-profit taxes }\end{array}$ & $\begin{array}{l}\text { Monte Carlo } \\
\text { simulation }\end{array}$ & $\begin{array}{l}\text { Internal rate of } \\
\text { return of the } \\
\text { project } \\
\text { Average effective } \\
\text { tax rate } \\
\text { Coefficient of } \\
\text { variation of } \\
\text { government } \\
\text { revenue } \\
\text { Coefficient of } \\
\text { variation of } \\
\text { private-sector } \\
\text { revenue }\end{array}$ \\
\hline $\begin{array}{l}\text { Samis et } \\
\text { al. (2007) }\end{array}$ & Gold & $\begin{array}{l}\text { MAP and } \\
\text { DCF }\end{array}$ & $\begin{array}{l}\text { Existing } \\
\text { project British } \\
\text { Columbia }\end{array}$ & $\begin{array}{l}\text { Initial situation: Mongolia: entire tax } \\
\text { system. } \\
\text { Simulation: addition of a super-profit tax }\end{array}$ & $\begin{array}{l}\text { Monte Carlo } \\
\text { simulation }\end{array}$ & Net present value \\
\hline $\begin{array}{l}\text { Thomas } \\
\text { (2010) }\end{array}$ & Gold & $\begin{array}{l}\text { Optimal } \\
\text { control }\end{array}$ & $\begin{array}{l}\text { Hypothetical } \\
\text { project }\end{array}$ & $\begin{array}{l}\text { Initial situation: Mali: Royalty, income } \\
\text { tax, taxes on dividends. } \\
\text { Simulation: Reduction in the royalty rate } \\
\text { from } 6 \% \text { to } 3 \% \text {. }\end{array}$ & No & Net present value \\
\hline
\end{tabular}




\section{References}

Allaire, Y. (2013) Le Québec et ses ressources naturelles: Comment en tirer le meilleur parti, report

Baker, M., Mayfield E., and Parsons, J. (1998) 'Alternative Models of Uncertain Commodity Prices for Use with Modern Asset Pricing Methods', The Energy Journal 19(1): 115-148

Baunsgaard, T. (2001) A Primer on Mineral Taxation, IMF Working Paper WP/01/139, IMF

Villafuerte, M., Poplawski-Ribeiro, M. and Richmond, C. (2012) Fiscal Framework for Resource Rich Developing Countries, IMF Staff Discussion Note 12/04, Washington: International Monetary Fund

Bird, F. (2014) 'The Practice of Mining and Inclusive Wealth Development in Developing Countries', Journal of Business Ethics, published online 10 October 2014, Springer

Blake, A. and Roberts, M. (2006) 'Comparing petroleum fiscal regimes under oil price uncertainty', Resources Policy 31: 95-105

Boadway, R. and Keen, M. (2010) 'Theoretical perspectives on resource tax design', in Daniel, P., Keen, M. and McPherson, C. (eds), The Taxation of Petroleum and Minerals: Principles, Problems and Practices, London: Routledge

Bohren, O. and C. Schilbred (1980) 'North Sea oil taxes and sharing of risk: a comparative study', Energy Economics 2(3): 145-153

Bradley, P. (1998) 'On the use of MAP for comparing alternative royalty systems for petroleum development projects', Energy Journal 19(1): 47-82

Brealey, R. and Myers, S. (2005), Principles of Corporate Finance, Irwin McGraw-Hill

Brennan, M. and Schwartz, E. (1985) ,Evaluating Natural Resource Investments', The Journal of Business 58(2): 145-153

Brewer, K., Bergevin, G. and Dunlop, R. (1989) 'Fiscal systems', Resources Policy 15(2) : 131-148

Campbell, B. (2004) Enjeux des nouvelles réglementations minières en Afrique, Research document 3, Nordiska Afrikainstitutet, Uppsala

Cawood, F. (1999) Determining the Optimal Rent for South African Mineral Resources, PhD dissertation, University of the Witwatersrand, Johannesburg

Charlet, A., Laporte, B. and Rota-Graziosi, G. (2013) 'La fiscalité minière en Afrique de l'Ouest et du Centre', Revue de Droit Fiscal 48: 11-33

Collier, P. and Venables, A. (2014) Closing Coal: Economic and Moral Incentives, OxCarre Working Papers 132, Oxford Centre for the Analysis of Resource Rich Economies, University of Oxford

Commonwealth Secretariat and ICMM (2009) 'Minerals Taxation Regimes. A review of issues and challenges in their design and publication', <icmm.com/document/520> 
Cordes, J. (1995) 'An Introduction to the Taxation of Mineral Rent', in J. Otto. (ed), The Taxation of Mineral Enterprises, London: Graham and Trotman

Crowson, P. (1998) 'Economic Rent and the Mining Industry', Journal of Mineral Policy, Business and Environment 13(2): 2-25

Daniel, P., Goldsworthy B., Maliszewski W., Mesa Puyo, D. and Watson, A. (2008) Evaluating Fiscal Regimes for Resource Projects: An Example from Oil Development, IMF Conference on Taxing Natural Resources

- Keen, M. and McPherson, C. (eds) (2010) The Taxation of Petroleum and Minerals: Principles, Problems and Practices, London: Routledge

Devereux, M. and Griffith, R. (2003) 'Evaluating Tax Policy for Location Decisions', International Tax and Public Finance 10(2): 107-126

Duncan, R. (2006) 'Price or Politics? An Investigation of the Causes of Expropriation', Australian Journal of Agricultural and Resource Economics 50(1): 85-101

Fullerton, D. and King, M. (1984) Taxation of Income from Capital, Chicago: University of Chicago Press

Garnaut, R. and Cluines-Ross, A. (1983) Taxation of Mineral Rents, Oxford: Clarendon Press

(1975) 'Uncertainty, Risk Aversion and the Taxing of Natural Resource Projects', Economic Journal 85: 272-287

Grinblatt, M. and S. Titman (2002) Financial Markets and Corporate Strategy, second edition, McGraw-Hill Irwin

Guj, P. (2012) Les redevances minières et autres impôts spécifiques à l'industrie minière, International Mining for Development Centre, Mining for Development: Guide to Australian Practice

and Garzon, R. (2007) Modern Asset Pricing - A Valuable Real Option Complement to Discounted Cash Flow Modelling of Mining Projects, Project Evaluation Conference, Melbourne, Australia

Hotelling, H. (1931) 'The Economics of Exhaustible Resources', Journal of Political Economy 39: $137-175$

IMF (2012) Regional Economic Outlook: Sub-Saharan Africa. Sustaining Growth Amid Global Uncertainty, World Economic and Financial Surveys, Washington DC: International Monetary Fund

Johnston, D. (2003) International Exploration Economics, Risk and Contract Analysis, Penwell, Tulsa

Khan, M. (2000) 'Rents, Efficiency and Growth', in M. Khan and K. Jomo (eds), Rents, RentSeeking and Economic Development, Cambridge University Press 
Land, B. (2008) Resource Rent Taxation - Theory and Experience, International Monetary Fund Conference

- (2007) Capturing a Fair Share of Fiscal Benefits in the Extractive Industry, background paper prepared for UNCTAD, London: Commonwealth Secretariat, mimeo

Laporte, B. and Rota-Graziosi, G. (2014) 'Principles and dilemmas in mining taxation', in M. Boussichas and P. Guillaumont (eds), Financing sustainable development. Addressing vulnerabilities, FERDI

Laughton, D. (1998) 'The Potential for Use of Modern Asset Pricing Methods for Upstream Petroleum Project Evaluation: Introduction', The Energy Journal 19(1): 149-153

Lund, D. (2009) 'Rent taxation for non-renewable resources', Annual Review of Resource Economics 1: 287-308

_ (1992) 'Petroleum taxation under uncertainty: contingent claims analysis with an application to Norway', Energy Economics 14: 23-31

McDonald, R. and Siegel, D. (1985) 'Investment and the valuation of firms when there is an option to shut down', International Economic Review 26(2): 331-349

Mackie-Mason, J. (1990) 'Some nonlinear tax effects on asset values and investment decisions under uncertainty', Journal of Public Economics 42(3): 301-327

Mansour, M. (2014) 'Une base de données sur les recettes fiscales en Afrique subsaharienne, 1980-2010', De Boeck Université, Revue d'économie du développement 22(3), 99-128

Moel, A. and Tufano, P. (2002) 'When are real options exercised? An empirical study of mine closings', The Review of Financial Studies 15: 35-64

Otto, J. (1998) 'Global changes in mining laws, agreements and tax systems', Resources Policy 24(2): 79-86

Andrews, C., Cawood, F., Doggett, M., Guj, P., Stermole F., Stermole, J. and Tilton, J. (2006) Mining Royalties: A Global Study of their Impact on Investors, Government, and Civil Society, Directions in Development, Energy and Mining, Washington: World Bank

and Cordes, J. (2002) The Regulation of Mineral Enterprises: A Global Perspective on Economics, Law and Policy, Westminster, Colorado: Rocky Mountain Mineral Law Foundation

and Batarseh, M. (2000) Global Mining Taxation Comparative Study, second edition, Golden CO: Colorado School of Mines

Podda Abouna, M., Boccanfuso D. and Savard, L. (2014) La fiscalité minière au Québec: Analyse comparatives des effets des redevances minières par la méthode du Modern Asset Pricing, mimeo, Université de Sherbrooke

Prichard, W., Cobham A. and Goodall A. (2014) ICTD Government Revenue Dataset, ICTD Working Paper 19, Brighton: International Centre for Tax and Development 
Radon, J. (2007) 'How to Negotiate an Oil Agreement?', in M. Humphreys, J. Sachs and J. Stiglitz (eds), Escaping the Resource Curse, New York: Columbia University Press

Ricardo, D. (1817) On the Principles of Political Economy and Taxation, London: John Murray

Salahor, G. (1998) 'Implications of output price risk and operating leverage for the evaluation of petroleum development projects', Energy Journal 19(1): 13-46

Samis, M., Davis G. and Laughton, D. (2007) Using stochastic discounted cash flow and real option Monte Carlo simulation to analyse the impacts of contingent taxes on mining projects, paper presented at the Project Evaluation Conference in Melbourne, Australia

Sandmo, A. (1979) 'A note on neutrality of the cash flow corporation tax', Economics Letters $4(2): 173-176$

Shafiee, S., Topal, E. and Nehring, M. (2009) 'Adjusted real option valuation to maximize mining project value - a case study using century mine', in Proceedings Project Evaluation Conference: 125-134, Melbourne, Victoria, 21-22 April 2009

Sinkala, T. (2009) Mining and the Environment in Africa. A Comprehensive Review Report, United Nations Environment Programme

Smith, J. (2013) 'Issues in extractive resource taxation: A review of research methods and models', Resources Policy 38: 320-331

— and McCardle, K. (1998) 'Valuing Oil Properties: Integrating Options Pricing and Decision Analysis Approaches', Operations Research 46: 198-217

Thomas, S. (2010) Mining Taxation: An Application to Mali, IMF Working Paper WP/10/126, Washington DC: International Monetary Fund

Tilton, J. (2004) 'Determining the Optimal Tax on Mining', Natural Resources Forum 28: 144149

Tordo, S. (2007) Fiscal Systems of Hydrocarbons: Design Issues, Working Paper 123/07, Washington DC: World Bank

Traoré, F. and Djiofack Zebaze, C. (2015) 'Managing depleting gold revenues in Mali: An assessment of policy options', Natural Resources Research, published online 23 May 2015

Vernon, R. (1971) Sovereignty at Bay: The Multinational Spread of U.S. Enterprises, The Harvard multinational enterprise series, Basic Books

World Bank (1992) Strategy of African Mining, Technical Paper 181, Africa Technical Department Series, Washington DC: World Bank 


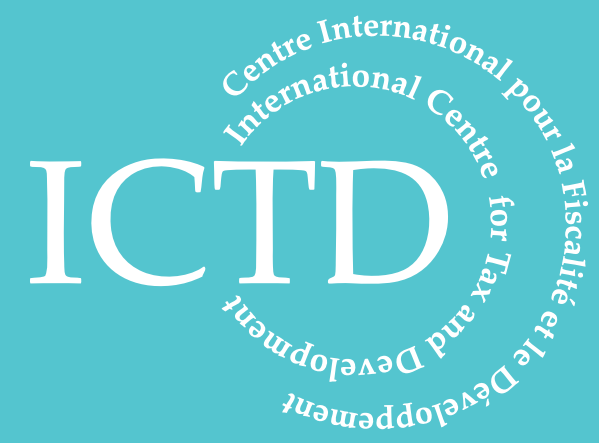

International Centre for Tax and Development at the Institute of Development Studies

Brighton BN1 9RE, UK

T: +44 (0) 1273606261

F: $+44(0) 1273621202$

E: info@ictd.ac

www.ictd.ac 